\title{
EFFECTS OF BETAMETHASONE ON THE COURSE OF EXPERIMFNTAI. INFECTION WITH TRYPANOSOMA CRUZI
}

\author{
Frederico G.C. Abath, Yara M. Gomes, Eridan M. Coutinho, \\ Silvia M.L. Montenegro, Maria E.B. Melo and Alexandre B. Carvalho
}

In this experiment, the effect of betamethasone administered in the early postacute infection of mice by Trypanosoma cruzi was studied. This drug was administered during 30 days after the $42^{\text {nd }}$ day of infection in a dose of $0.15 \mathrm{mg} /$ day. The betamethasone treatment did not cause fresh outbreaks of parasitemia and the histopathological findings in the chronic phase were not different from those in the control group. The higher cumulative mortality after treatment in the experimental group was due to superimposed bacterial infections. Outbred albino mice infected with low numbers of $Y$ strain Trypanosoma cruzi trypomastigotes were not suitable models for Chagas' disease, since after 7 months of observation only mild histological lesions developed in all the animals. Prolonged betamethasone treatment of mice infected with low numbers of Trypanosoma cruzi of the Y strain, during the post-acute phase did not aggravate the course of infection.

Key words: Chagas' disease. Trypanosomiasis. Immunosuppression. Betamethasone. Light Trypanosoma cruzi infection.

The pathogenesis of chagasic cardiopathy has not yet been completely explained. However, several papers support the hypothesis that autoimmune mechanisms are involved 1101218 . At present there is no experimental chronic Chagas' disease model of general acceptance ${ }^{6}$, even though the canine 23 and the rabbit ${ }^{19}$ models have been suitable for some purposes. Recently, Laguens et al. ${ }^{9}$ proposed a mouse model using the Tulahuen strain of Trypanosoma cruzi in a low dose inoculum. The effects of immunosuppressive treatment during the acute phase 13141517 or the established chronic phase of the disease are known 781415 . However immunosupression in the early post-acute phase has not been extensively investigated.

The purpose of the present paper is to evaluate: 1) the suitability of low dose infection of mice with the Y strain of Trypanosoma cruzi as a model of Chagas' disease; 2 ) if immunosuppression in the early postacute phase alters the course of infection.

\section{MATERIAL AND METHODS}

Animals: Outbred Swiss 3 month old albino male mice were used, weighing $35 \pm 4,5 \mathrm{~g}$ (mean \pm Standard deviation).

Endereço para correspondència:

Centro de Pesquisas Aggeu Magalhães, Rua do Espinheiro, 106, 50000 Recife, PE, Brasil.

Recebido para publicação em 25/11/1985.
Infection: Twenty five blood trypomastigotes of the Y strain of $T$. cruzi (obtained from Dr. M.P. Deane, FIOCRUZ, Rio de Janeiro, in October 1983 and mantained by weekly passages in mice since then) were inoculated intraperitoneally. The inoculum estimation was done using a Neubauer hemocytometer.

Experimental group: Thirty infected and betamethasone treated mice.

Control group: Fifteen infected and non-treated mice.

Betamethasone: This drug was administered from the $42^{\text {nd }}$ to the $75^{\text {th }}$ day after inoculation by esophageal intubation in a dose of $0.15 \mathrm{mg} / \mathrm{day}$.

Parasitemia and mortality: the parasitemia wasestimated by Brener's technique 5 at $5,10,15,21,30$, $40,65,80$ and 120 days after infection. Dead mice were removed daily.

Morphological study: All mice that had died spontaneously and those killed seven months after infection were autopsied. Samples from all the examined organs (heart, striated muscle, liver, spleen, intestines, kidneys and lungs) were fixed in $10 \%$ neutral formalin, embedded in paraffin, and sections cut at 5 micrometers and stained by hematoxylineosin and Mallory-Russel trichrome.

Statistical analysis: The parasitemias were compared by the " $t$ " test and differences between cumulative mortality rates, were evaluated by normal approximation. The significance level accepted was 0.05 . 
Abath FGC, Gomes YM, Coutinho EM, Montenegro SML, Melo MEB, Curvalho AB. Effects of betamethasone on the course of experimental infection with Trypanosoma cruzi. Revista da Sociedade Brasileira de Medicina Tropical 19: 161-164, Jul-Set, 1986

\section{RESULTS}

The levels of parasitemia attained in all $T$. cruzi infected mice in the acute phase of the infection, are shown in Figure 1. The peak of parasitemia was reached at the $10^{\text {th }}$ day after infection, when mice presented $8 \pm 2(\mathrm{X} \pm \mathrm{SD})$ parasites $/ 50$ microscopic fields of $400 \times$ magnification. On the $40^{\text {th }}$ day after inoculation only $2 / 38$ of the mice continued with patent parasitemia ( 1 parasite/50 fields of $400 \mathrm{X}$ ) and parasitemia was negative thereafter.

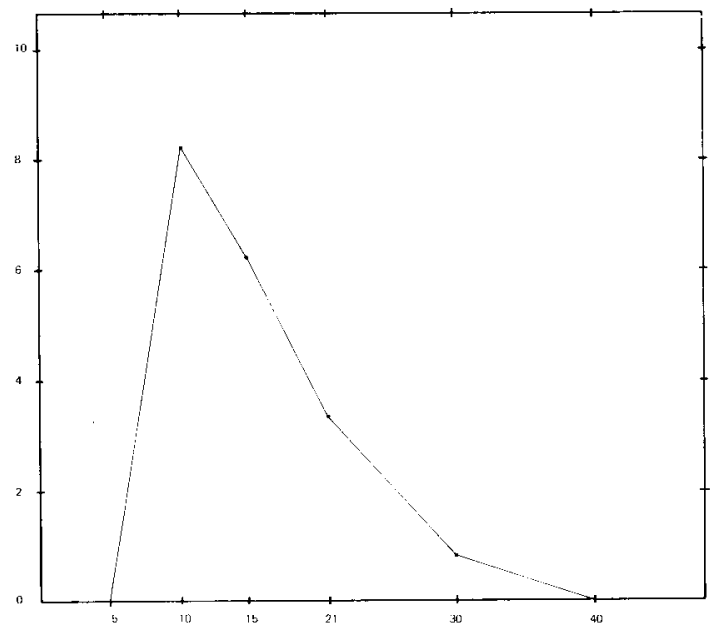

Figure 1 - Parasitemia of mice infected with 25 Y strain T.cruzi trypomastigotes.

As far as parasitemia was concerned, the betamethasone treated group did not differ from the control group, since no blood parasites were detected after immunosuppression.

The mortality in the acute phase was very low $(8.0 \%)$. The cumulative mortality between the $42^{\text {nd }}$ and the $200^{\text {th }}$ day after infection is shown in Figure 2. At the end of the experiment the mortality rate observed in the experimental group (69.6\%) as

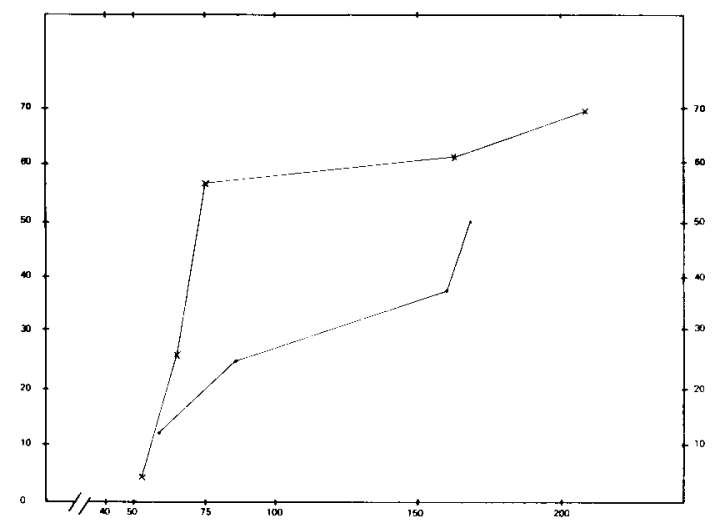

Figure 2 -Cumulative mortality in the betamethasone treated $(\longrightarrow x)$ and non treated $(\longrightarrow$ infected mice. compared to that seen in the control $(50 \%)$, was not significant, but after betamethasone treatment ( 75 days after inoculation) mortality was significantly higher in the experimental $(56.5 \%)$ than in the control group (12.5\%).

Morphological study: No gross lesions were detected in the hearts examined. In the acute phase of infection, only one mouse out of three that died spontaneously, showed a subacute, diffuse myocarditis with the presence of some pseudocysts in the myocardial fibers (Fig. 3). In the chronic phase of infection, the histopathological findings were mild and not important. Focal mononuclear infiltrates either in the myocardial interstitium or under the epicardium layer were seen as well as in the neighbourhood of parasympathetic ganglia neurones displaying chromatolysis and other regressive lesions. Microfoci of myocardial fibrosis and myocytolysis were detected.

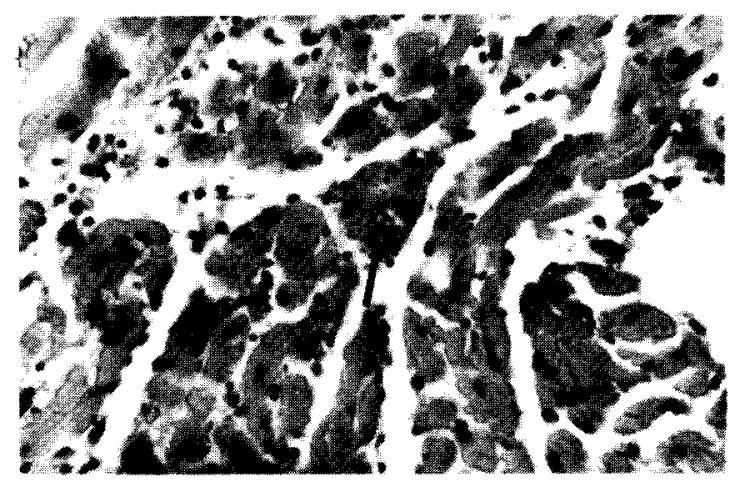

Figure 3 - Mild lymphocytic interstitial infiltration and degenerative lesions in the myocardium of an acutely infected mouse. A pseudocyst of $\mathrm{T}$. cruzi is in the center of the field (arrow). Hematoxylin/eosin (x 200).

However these findings were not different from those observed in the control group. In the experimental group, the lesions seen in other organs were most frequent in the lungs and kidneys and resulted from superimposed bacterial infections. Septicemia was the most frequent cause of death, as indirectly evidenced through the frequent development of micro-abscesses in lungs, kidneys, spleen and liver; pulmonary oedema and hemorrhages; intensive generalized congestive changes; acute renal tubular necrosis and development of intensive acute cutaneous and organ infections (splenitis, pneumonitis, nephritis). These histological lesions have been taken as evidence that the administration of betamethasone by esophageal intubation had been effective in inducing immunosuppression in 
Abath FGC, Gomes YM, Coutinho EM, Montenegro SML, Melo MEB, Carvalho AB. Effects of betamethasone on the course of experimental infection with Trypanosoma cruzi. Revista da Sociedade Brasileira de Medicina Tropical 19:161-164, Jul-Set, 1986

the animals. Liver and spleen amyloidosis were observed in seven mice from the experimental group and in none of the control animals.

Variable splenomegaly was observed in mice which died in the acute phase of infection ( 3 animals), as well as those in the chronic phase showing associated bacterial infections.

\section{DISCUSSION}

Laguens et al. ${ }^{9}$ demonstrated by morphological, immunological and electrocardiographic studies that the infection of three month old outbred mice with a low number of trypomastigotes of a highly pathogenic strain of $T$. cruz $i$ (Tulahuen strain) leads to a chronic illness showing remarkable similarities to human Chagas' disease. However, in the present experiment the infection of outbred mice with a small inoculum of $T$. cruzi (Y strain) did not seem to be a suitable model for Chagas' disease. The histopathological findings were very mild, either in acute or chronic phases. Probably, the model proposed by Laguens et al. ${ }^{9} 11$ is dependent on the particular properties of the Tulahuen strain. The parasitemia and mortality rate were low and the parasitemic peak was delayed in our model, in comparison to the behavior of the $\mathrm{Y}$ strain of $T$. cruzi when high dose infections are induced.

The betamethasone treatment during 30 days in the period that followed immediately the acute phase, did not seem to reactivate the infection, since blood trypomastigotes could not be detected again. The effects of immunosupression during acute Chagas' disease are well known ${ }^{13} 141517$ rendering the infection more severe. On the other hand, the administration of cortisone does not seem to alter the course of chronic infection in the rat ${ }^{15}$ or mouse ${ }^{7}$. Brener $\&$ Chiari ${ }^{8}$ have demonstrated that gamma radiation and cyclophosphamide could induce, in mice inoculated with the $\mathrm{CL}$ strain, an acute phase with outbreaks of high parasitemia and high mortality rate, whereas no increase of parasitemia was observed in animals inoculated with the $Y$, Berenice and PNM strains and similarly treated during the chronic phase. Additionally, some chronic chagasic patients submitted to immunosuppressive treatment did not apparently show any alterations in the course of the disease ${ }^{4}$. However Rassi et al. ${ }^{16}$ observed increase of parasitemia in 8 out of 11 chronic chagasic patients treated with corticoid.

The higher cumulative mortality after corticoid treatment as seen in the experimental group in this paper, was due to superimposed bacterial infections.

The occurrence of severe infections complicated by septicemias was very high in this group indicating that the betamethasone dosage was effective. It can therefore be concluded that under the present experimental conditions, betamethasone treatment during the early post-acute phase does not modify the course of chronic Chagas'disease, since neither the experimental nor the control groups showed characteristic lesions of the chronic illness.

\section{RESUMO}

Foram estudados os efeitos da betametasona administrada na fase pós-aguda imediata de uma infecção pelo $\mathrm{T}$. cruzi em camundongos. $O$ tratamento consistiu de 30 doses diárias de $0,15 \mathrm{mg}$ de betametasona, a partir de $42 .^{\circ}$ dia de infecção, não havendo aparecimento de novos surtos de parasitemia. No tempo de duração do experimento (7 meses) não houve diferença entre as lesões histopatológicas dos animais tratados e dos não tratados. O grupo experimental apresentou uma maior mortalidade acumulada no 75.o dia de infecção, o que pode ser atribuido a infecções bacterianas associadas. Por outro lado, camundongos albinos "outbred", infectados com baixo inóculo, não se apresentaram como bom modelo de doença de Chagas, já que não desenvolveram lesões importantes nem na fase aguda nem após 7 meses de infecção. Em conclusão, o tratamento imunosupressivo prolongado, após a fase aguda de uma infecção mínima com a cepa $Y$ do T. cruzi não tem influência sobre o curso da infecção, pelo menos no que tange ao agravamento da mesma.

Palavras chaves: Doença de Chagas. Tripanosomiase. Tratamento imunossupressivo. Betametasona. Infecção minima pelo Trypanosoma cruzi.

\section{REFERENCES}

1. Andrade ZA. Aspectos patológicos da doença de Chagas. Interciência 8: 367-373, 1983.

2. Andrade ZA, Andrade SG. A patologia da doença de Chagas experimental no cão. Memórias do Instituto Oswaldo Cruz 75:77-95, 1980.

3. Andrade SG, Andrade ZA, Sadigursky M. Combined treatment with a nitrofuranic and a corticoid in experimental Chagas' disease in the dog. American Journal of Tropical Medicine and Hygiene 29: 766-773, 1980.

4. Barousse AP. Enfermedad de Chagas e imunosupresión. Medicina 40:896, 1980.

5. Brener Z. Contribuição ao estudo da terapêutica experimental da doença de Chagas. Tese. Faculdade de Odontologia e Farmácia, Belo Horizonte, 1961.

6. Brener $Z$. Progrès récents dans le domaine de la maladie de Chagas. Bulletin de l'Organization Mondiale de la Santé 60: 845-856, 1982

7. Brener Z, Chiari E. Observações sobre a fase crônica da doença de Chagas experimental no camundongo. Revista do Instituto de Medicina Tropical de São Paulo 5: 128-132, 1983.

8. Brener Z, Chiari E. The effects of some immunosuppressive agents in experimental chronic Chagas' 

of experimental infection with Trypanosoma cruzi. Revista da Sociedade Brasileira de Medicina Tropical 19:161-164, Jul-Set, 1986

disease. Transactions of the Royal Society of Tropical Medicine and Hygiene 65: 629-636, 1971.

9. Laguens RP, Meckert PC, Basombrio MA, Chambo GJ, Cossio PM, Arana RM, Gelpi RJ. Infección crónica del raton com Trypanosoma cruzi. Modelo experimental de enfermedad de Chagas. Medicina 40 (Supl. 1): 33-39, 1980.

10. Laguens RP, Meckert PC, Chambo G, Gelpi RJ. Chronic Chagas' disease in the mouse. II Transfer of the heart disease by means of immunocompetent cells. Medicina 41: 40-43, 1981.

11. Laguens RP, Meckert PC, Gelpi RJ. Chronic Chagas' disease in the mouse. I Electrocardiographic and morphological patterns of the cardiopathy. Medicina 41: 35 39, 1981

12. Macêdo V. Forma indeterminada da doença de Chagas. Jornal Brasileiro de Medicina 38: 34-40, 1980.

13. Nery-Guimaràes F, Lage HA. Ação da cortısona e da betametasona na doença de Chagas experimental. I. Camundongos. O Hospital 77: 133-146, 1970.

14. Pizzi T, Chemke J. Acción de la cortisona sobre la infección experimental de la rata por Trypanosoma cruzi. Biológica 21: 31-58, 1955.

15. Pizzi T, Rubio M, Prager R, Silva R. Acción de la cortisona en infección experimental por Trypanosoma cruzi. Boletin de Infecciones Parasitarias Chilenas 7: 22-24, 1952.

16. Rassi A, Doles J, Cardoso VM, Silva OQ, Leite MSB. Aumento da parasitemia na fase crônica da doença de Chagas humana, na vigência de terapêutica corticosteróide. Arquivos Brasileiros de Cardiologia 23 (Supl. 1): 55, 1970.

17. Schmunis GA, Gonzalez Cappa SA, Traversa OC, Janovsky FF. The effect of immunodepression due to neonatal thymectomy on the infections with Trypanosoma cruz $i$ in mice. Transactions of the Royal Society of Tropical Medicine and Hygiene 65: 8-94, 1971.

18. Teixeira ARL. Patogenia da doença de Chagas. Jornal Brasileiro de Medicina 38: 23-33, 1980.

19. Teixeira ARL, Figueiredo F, Rezende Filho J, Macèdo V. Chagas' disease: a clinical, parasitological, and pathological study in rabbits. American Journal of Tropical Medicine and Hygiene 32: 258-272, 1983. 